\title{
Preliminary results of the atmospheric leakage dispersion modeling of the Brazilian $\mathrm{CO}_{2}$ Pilot
}

\author{
A. Moreira ${ }^{1,2}$, J. C. Almeida ${ }^{3}$, S. Oliveira ${ }^{4}$,W. Nakaema ${ }^{5}$, \\ E. Landulfo ${ }^{5}$, F. Rosario ${ }^{1}$, A. P. Musse ${ }^{1}$, M. Bruno ${ }^{2} \&$ S. Correa ${ }^{2}$ \\ ${ }^{1}$ PETROBRAS Research Center (CENPES), Brazil \\ ${ }^{2}$ Multidisciplinary Post Graduate Program in Environmental Sciences, \\ Rio de Janeiro State University (PPGMA/UERJ), Brazil \\ ${ }^{3}$ Rio de Janeiro Pontifical Catholic University, PUC, Brazil \\ ${ }^{4}$ Climatic and Environmental Studies System, SECA, Brazil \\ ${ }^{5}$ Energy and Nuclear Research Institute, IPEN, Brazil
}

\begin{abstract}
The Brazilian $\mathrm{CO}_{2}$ Pilot Project was started off in 2012 in Florianopolis, SC, at a $6,280 \mathrm{~m}^{2}$ experimental cell located at the Ressacada Farm, Santa Catarina Federal University (UFSC), fully sponsored by PETROBRAS Research Center (CENPES). This pioneer initiative was carried out as a technical cooperation among CENPES, the Brazilian Academy and international researchers, to provide field infrastructure for carbon dioxide simultaneous detection in the open environment, encompassing the atmosphere, subsurface and soil. The project goals are to deploy, test and assess the multiple measurement tools simultaneously deployed on site during $\mathrm{CO}_{2}$ controlled releases. These methodologies are likely to be applied in future large scale carbon sequestration sites. This work presents the initial results of the atmospheric dispersion modeling studies and an overview of the atmospheric measurements carried out in the $2013 \mathrm{CO}_{2}$ controlled release, in which a standard $\mathrm{CO}_{2}$ Eddy Covariance System (ECS) and a $\mathrm{CO}_{2}\left(\right.$ delta $\left.^{13} \mathrm{C}\right)$ Isotope Gas Analyser (IGA) were deployed to track $\mathrm{CO}_{2}$ in the air. Dispersion studies, currently at an early stage, were carried out using AERMOD 8.8.9. Results showed overall consistent trends, when comparing the outcome from the monitoring set as well as when confronting model output with experimental data.
\end{abstract}

Keywords: geological carbon sequestration, $\mathrm{CO}_{2}$ controlled release, atmospheric dispersion modelling, Eddy covariance, isotopic measures. 


\section{Introduction}

As shown in the latest IPCC Assessment Report [1], the urgent need to deploy more effective - and restrictive - climate change mitigation measures is reinforced, making Greenhouse Gas (GHG) emissions abatement strategies an undeniable global priority not to be postponed. In such a context, the urge to launch large scale Geological Carbon Sequestration (CCS) projects, rapidly enabling massive carbon dioxide emissions reduction, became even more strategical to the oil industry $[1,2]$.

To date, one of the most critical challenges hindering the establishment of CCS on a global scale is to ensure effective permanence and containment of the $\mathrm{CO}_{2}$ in the geological formation (sink), with the minimum quantifiable leakage risks that the gas might escape the storage reservoir and hence impact the shallow groundwater aquifers or migrate back into the atmosphere. This reinforces the importance of making effective, reliable and robust $\mathrm{CO}_{2}$ monitoring techniques readily available $[3,4]$ and emphasizes the importance of Carbon Dioxide Measurement, Monitoring and Verification $\left(\mathrm{CO}_{2} \mathrm{MMV}\right)$ technologies as a fundamental component of the Carbon Management Strategies, targeting climate change mitigation, as well as contributing to overall public acceptance $[5,6]$.

On a world basis, a variety of monitoring techniques for the shallow groundwater, soil and atmosphere have been developed, tested, upgraded and deployed over time; nevertheless, the degree of underlying technical maturity varies substantially. Eddy covariance and isotopic measures have been deployed with success elsewhere [7, 8], however the relatively high natural $\mathrm{CO}_{2}$ fluctuations in the open environment eventually compromises the quantification and/or detection of potential $\mathrm{CO}_{2}$ leaks from the reservoir and poses a huge challenge yet to be overcome, mostly due to the off-set in background natural variability and the detection limits of the techniques currently available [6]. Quantification is especially critical in the atmospheric compartment, given the high dilution rates.

This work presents the preliminary assessment of the physical transportation and downwind ground level concentration distribution for an ambient temperature, dense gaseous $\mathrm{CO}_{2}$ atmospheric plume, originated from the controlled gas release experiment carried out in the $\mathrm{CO}_{2}$ Pilot Project, resorting to a simple Gaussian dispersion model, aiming to help the interpretation of the experimental results. The choice of AERMOD is justified by its overall reliability [9] and the endorsement of the environmental regulators in the permitting process for the industry in Brazil, with focus in the oil and gas business [10], together with the attractive cost-effectiveness of this easier to use modeling tool, given the site features and the nature of the release experiment presented herein. 


\section{Brazilian $\mathrm{CO}_{2}$ Pilot Project background}

\subsection{Motivation and site features}

As part of the Brazilian National Oil Company (PETROBRAS) Strategical Plan and aiming to reduce the technical gaps in $\mathrm{CO}_{2} \mathrm{MMV}$, several initiatives were carried out to accelerate technical expertise build-up at the national level, as well as providing minimum required infrastructure so as to start up longer term $\mathrm{R} \& \mathrm{D}$ Projects. Therefore the Brazilian $\mathrm{CO}_{2}$ MMV Field Lab was officially initiated in 2012, under the full sponsorship of PETROBRAS Research Center (CENPES) and managed by its Atmospheric Emissions Mitigation Technological Program (EMISSIONS). An unprecedented initiative at the national level and unique in Latin America, the project was custom-designed to fill the knowledge gaps of $\mathrm{CO}_{2}$ management technologies, with long term goals to level-off Brazil in the international scenario and provide technical solutions for the country's climate change mitigation strategies. The basic motivations to establish the $\mathrm{CO}_{2}$ Pilot were: (1) creating expertise; (2) deploying and assessing $\mathrm{CO}_{2}$ monitoring and verification technologies, currently available or under development, so as to support the construction of solid, sound requisite monitoring plans likely to be contemplated in future regulations for $\mathrm{CO}_{2}$ storage projects; (3) catalyzing systematic experimental assessment of local $\mathrm{CO}_{2}$ environmental dynamics.

The Ressacada Experimental Farm is a ca 157 ha property, ran by Santa Catarina Federal University Agronomic Sciences Department (UFSC/CCA), chosen to house the $\mathrm{CO}_{2} \mathrm{MMV}$ field lab, mostly for having already hosted several controlled release experiments of solid and liquid contaminants, as well as soil and aquifer remediation research projects, all totally sponsored by PETROBRAS, with the endorsement of the local environmental agent (FATMA). The Pilot Site is located ca $1.7 \mathrm{~km}$ south of the Hercilio Luz International Airport and ca $0.9 \mathrm{~km}$ east of the Tapera Community, in a complex mixed profile area, in which: (1) plenty, robust and diverse profile anthropogenic $\mathrm{CO}_{2}$ sources are present in the local airshed, such as mobile sources (vehicles, airplanes, farming machinery etc); stationary and area sources (wood and debris burning; natural gas for heating and cooking; small scale business and service suppliers); (2) very strong non-anthropogenic $\mathrm{CO}_{2}$ contributions coming from the local native and cultivated vegetation, including a variety of grasses, as well as $\mathrm{C} 4$ plants.

Site main features are the local climate classified as Subtropical Humid [11], with typical surface temperatures ranging from 13 to $25^{\circ} \mathrm{C} ; 1,627 \mathrm{~mm}$ average rainfall per year, well distributed throughout the seasons; in terms of wind circulation patterns, there is a clear prevalence of winds coming from the northern quadrants [11-14]. The aquifer is unconfined and very shallow, ranging from $0.4 \mathrm{~m}$ to $1.3 \mathrm{~m}$ depth, with a low gradient $(0.4 \%)$ and flows $\mathrm{E}-\mathrm{W}$, at 6.3 m.year ${ }^{-1}$ on average. 


\subsection{The 2013 release experiment}

The $\mathrm{CO}_{2}$ MMV field lab experimental cell is located at $\left(27^{0} 41^{\prime} 02.19^{\prime \prime} \mathrm{S}\right.$ latitude), (48 $32^{\prime} 41^{\prime \prime} \mathrm{W}$ longitude), $1.84 \mathrm{~m}$ elevation and spreads over a 6,280 $\mathrm{m}^{2}$ area, next to the main administration and lab facilities building. A schematic plot (shown in Figure 1), illustrates the spatial distribution of the main techniques and detectors used in the injection campaign, with the main associated grids.

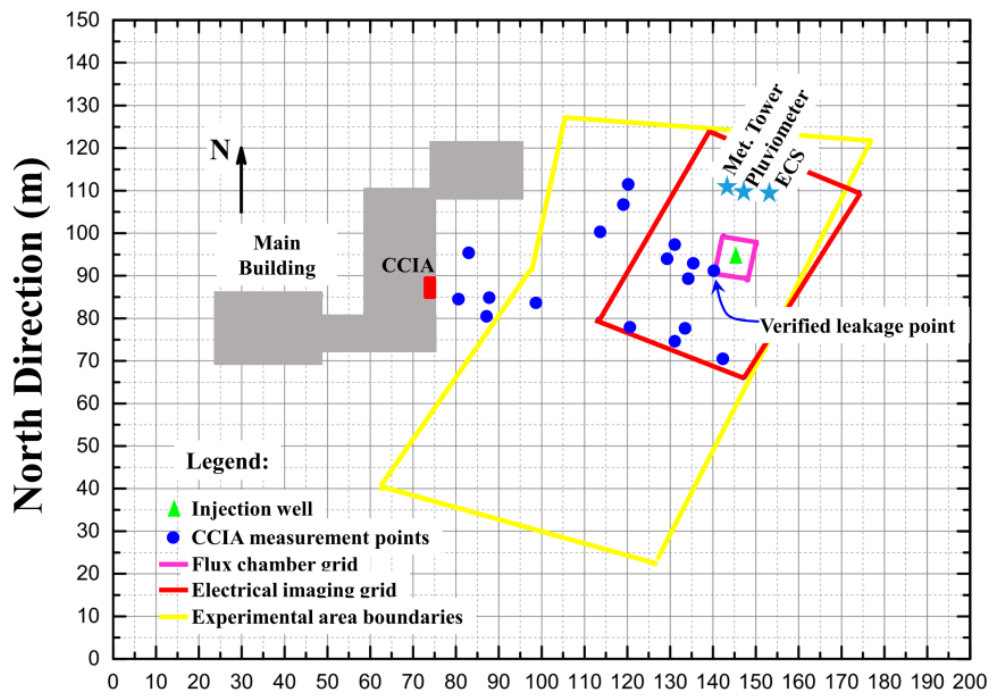

\section{East Direction (m)}

Figure 1: Schematic detail of the experimental cell and sampling locations.

The $2013 \mathrm{CO}_{2}$ controlled release experiment was carried out from 10th to 21st September 2013. Food-grade gaseous $\mathrm{CO}_{2}, 99.99 \%$ purity was fed to a single 3-meter vertical injection well, located at $(6935.466 \mathrm{~N}),(742.183 \mathrm{E})$, through a gas cylinder housed away from general personnel site circulation. After being injected into the soil, the gas was let leak freely back into the environment. $\mathrm{CO}_{2}$ detection and measurements were provided resorting to the deployment of the variety of methodologies described herein. $\mathrm{CO}_{2}$ injection in the underground was carried out through a single vertical injection well (highlighted in Figure 1), which key parameters were 1" diameter, 3m depth, PVC cased and $30 \mathrm{~cm}$ screen-section. Well constructive details, injection infrastructure and logistics are detailed in $[12,13]$.

Decision was taken to keep the lowest gas injection rates possible throughout the experiment, so as to avoid potential sediments collapsing, thus minimizing the risk of chimney effect, as detailed before $[12,13]$. Therefore gas injection rates ranged from 90 to $150 \mathrm{~g} / \mathrm{h}$, with a total amount of ca $33 \mathrm{~kg}$ of $\mathrm{CO}_{2}$ being fed into the ground by the end of the injection campaign. The main benefit of such low injections was literally nil health or safety hazards risks to human 
receptors as well as likely environmental impacts (refer to AERMOD results displayed in Figure 2 and Table 1); additionally, all required safety protocols and instructions were made available to the technical personnel and proper signalization of less ventilated areas was provided. Nevertheless, a severe drawback of such low gas release rate was the difficulty in quantifying the impact likely to be attributed to our experiment, especially taking into consideration the high variability of background conditions and the complexity of the local ecosystem, as indicated both by the experimental and modelled results presented in this work.

\section{$2.3 \mathrm{CO}_{2}$ monitoring methodologies deployed on site for the 2013 release}

$\mathrm{CO}_{2}$ monitoring was carried out prior to the injection campaign, during the release and after ceasing the injection, roughly covering 45 days of field work, the exact timing varying with each technique specificities. Carbon dioxide atmospheric detection was carried out on a routine and continuous basis at the micrometeorological scale (refer to [13] for more details). The parameters covered were:

- $\mathrm{CO}_{2}$ atmospheric fluxes and concentrations continuously monitored by an open-path Eddy-Covariance System (EC or ECS), manufactured by IRGASON-Campbell Scientific, installed $8 \mathrm{~m}$ upwind of the injection well, together with a $3 \mathrm{D}$ sonic anemometer and the $\mathrm{CO}_{2} / \mathrm{H}_{2} \mathrm{O}$ detectors, mounted on a 2-m high tripod, next to the standard meteorological tower dedicated to the project;

- $\mathrm{CO}_{2}$ isotopic composition analysis $\left({ }^{13} \mathrm{C},{ }^{12} \mathrm{C}\right.$ isotopes concentration and ratio) using the Isotope Gas Analyzer (IGA, also referred to as CCIA) manufactured by Los Gatos Research Inc, based upon an Off-Axis Cavity Ring Down System (CRDS);

- standard surface meteorological parameters were continuously monitored by the project met tower (Campbell Scientific Inc. Model UT30), recording horizontal wind speed and direction, atmospheric pressure and temperature; rainfall and total solar radiation;

- targeting the simultaneous monitoring of $\mathrm{CO}_{2}$ in the other environmental compartments, the methodologies deployed covered: (a) subsurface detection, by measuring soil gas fluxes and concentration, using accumulation chambers; (b) geophysical monitoring, resorting to soil and subsurface electro-resistivity surveys; (c) shallow aquifer water quality characterization, based upon manual sampling at different depth levels (refer to $[12,13]$ for details covering each methodology).

\section{$3 \mathrm{CO}_{2}$ atmospheric modeling}

\subsection{AERMOD}

The model chosen to run the atmospheric dispersion for the $2013 \mathrm{CO}_{2}$ controlled release campaign was the shareware steady-state Gaussian plume software, 
known as AERMOD (AMS/EPA Regulatory Model), a joint development of the American Meteorological Society and the American Environmental Protection Agency [9].

Since 2006, AERMOD is officially considered USEPA's preferred model for both simple and complex terrain assessment, recommended and endorsed by EPA for the use in regulatory discussions. Following this trend AERMOD is also recommended by the environmental regulators in Brazil [10], in the course of general permitting processes for industrial applications as well as air quality assessment studies.

AERMOD is a three-module integrated modeling system, designed to calculate atmospheric dispersion of continuous emission plumes, based on planetary boundary layer turbulence structure and scaling concepts, including treatment of sources of multiple categories (point, area and volume sources), on urban or rural locations, simple and complex terrains, surface, near surface and elevated surface. The built-in modules are: (1) AERMET, the meteorological module that preprocesses primary meteorological parameters input by the user (such as surface meteorological data, upper air soundings, and data generated locally by on-site instrument towers) required to generate the necessary atmospheric turbulence, mixing heights, friction velocity, Monin-Obukov length and surface heat flux etc, deployed in the atmospheric dispersion calculations; (2) AERMAP, the terrain module, that preprocesses the terrain features informed by the user, generating location and height data for each receptor location, thus providing a physical relationship between terrain features and the behavior of air pollution plumes that enables the calculation of more realistic atmospheric dispersion; (3) short-range (up to 50 kilometers) dispersion of air pollutant emissions from multiple categories of stationary sources.

For the detailed description of the model formulation and parametrizations, refer to [9]. In order to fit the modelling study to our experiment conditions, the model was run considering no plume elevation effects, with the $\mathrm{CO}_{2}$ emissions homogeneously leaking from a ground-level area source at constant rate, at ambient temperature and pressure (dense gas plume).

\subsection{Meteorology and terrain features}

Surface meteorological data covering June 2012 to October 2013 were retrieved from the local meteorological station (METAR 83749 SBFL or Florianopolis Hercilio Luz International Airport), operated by the Aeronautics Meteorology Net [14]. These data were input in AERMETView (AERMOD Meteorological Preprocessor, a proprietary Windows interface platform [15], and were used to compose the modeling scenarios for the Ressacada airshed.

Data provided by our local met tower showed good overall consistency with the airport meteorological station data, as well as historical times series, as detailed in [13].

The upper-air parameters also required for the atmospheric dispersion, such as inversion height estimates and boundary layer calculations, were parametrized resorting to the standard AERMET calculations, once radio soundings are not carried out at Florianopolis Airport. 
For the first phase of our modeling study, AERMET was ran bracketing 8th to 22nd September 2013, so as to portray the meteorological features of the two main scenarios: $\mathrm{CO}_{2}$ background quick assessment (8th and 9th September) and the release experiment (from 10th September onwards). After 22nd September, $\mathrm{CO}_{2}$ controlled injection was fully stopped; therefore post injection conditions were not included in the model.

Local terrain is flat (maximum elevations within the Ressacada Farm are less than $4 \mathrm{~m}$ above sea level), not obstructing natural surface wind flow. Nevertheless the existing irregularities were treated by AERMAP upon the input of local digital elevation information, retrieved from satellite data (SRTM3/SRTM11 - Shuttle Radar Topography Mission) using the AERMAP View preprocessor.

\section{3 $\mathrm{CO}_{2}$ emissions and leakage area}

To our knowledge there has been no record of systematic $\mathrm{CO}_{2}$ measurements or surveys at the local level prior to this study and nor local $\mathrm{CO}_{2}$ emissions inventory. Hence, decision taken was to perform the simulation exclusively considering our $\mathrm{CO}_{2}$ controlled release experiment. Therefore no other $\mathrm{CO}_{2}$ sources were input to the model for this initial assessment. The complexity of local $\mathrm{CO}_{2}$ atmospheric emissions sources and dynamics, as mentioned before, justified the adoption of such simplification.

AERMOD was run for the September 2013 release, solely considering the $\mathrm{CO}_{2}$ emissions coming from the injection carried out in the controlled release experiment. By doing so $\mathrm{CO}_{2}$ background concentrations were equaled to zero.

When confronted to experimental data, dispersion model results correspond to the net concentration differences, as in (1):

$$
\left[\mathrm{CO}_{2}\right]_{\text {modelled }}=\left[\mathrm{CO}_{2}\right] \text { measured during release }-\left[\mathrm{CO}_{2}\right] \text { measured background }
$$

Hourly values of $\mathrm{CO}_{2}$ emissions were kept constant throughout the modeled period; the corresponding effect of $\mathrm{CO}_{2}$ breakthrough within the experimental cell - roughly 5 days after the injection began (as detailed in $[5,12,13]$ ) - was accounted for by averaging out the total amount of $\mathrm{CO}_{2}$ injected throughout the 2013 experiment, ca $33 \mathrm{~kg}$, from 15th to 21 st September 2013.

Additionally, as supported by the assessment of the results gathered from the other methodologies deployed on site $[12,13]$, we concluded that $\mathrm{CO}_{2}$ retention within the local soil is likely to have been low or negligible; hence it was assumed that all the $\mathrm{CO}_{2}$ injected in the soil leaked back into the atmosphere.

For the sake of consistency, the spatial distribution of the $\mathrm{CO}_{2}$ leaking area for input in the model was also assessed; several modeling scenarios were built (not shown, due to space limitations). Based upon the integrated assessment of the soil flux chamber results $[12,13]$ confronted with the Carbon isotope screening measurements [13], a $400 \mathrm{~m}^{2}$ leakage area, surrounding the $3-\mathrm{m}$ deep injection well at $(6935.466 \mathrm{~N}),(742.183 \mathrm{E})$ (displayed in Figure 1), provided a more realistic fitting for the highest measured leaking spots and also contemplated the integrated results of all the methodologies deployed on site. 
Modelled $\mathrm{CO}_{2}$ leakage rate was assumed to be constant and homogeneously distributed throughout the leakage area, at the ground-level.

\subsection{Modeling grid and receptors}

AERMOD was run for a $400 \mathrm{~m}^{2} \mathrm{CO}_{2}$ leakage area centered around the injection well. Calculations were performed in a modelling domain of $1.6 \mathrm{~km} \times 1.6 \mathrm{~km}$, with the geometric center at the injection well location (not shown, due to space limitations). Embedded in this grid, a 256 receptor and $200 \mathrm{~m}^{*} 200 \mathrm{~m}$ subgrid was set, in order to allow a more comprehensive assessment of the study (displayed in Figure 2).

The discrete receptors chosen were: (1) next to the experimental cell: the green building (also referred to as the main administration building), the window (or the shelter at which the Carbon Isotopic Analyser was kept) and the Eddy Covariance location (so as to allow the comparison of the modeled results with the $\mathrm{CO}_{2}$ air concentration experimental data) ; (2) the Airport (Hercilio Luz International Airport), less than $1.7 \mathrm{~km}$ away; (3) Tapera, the local community, situated ca $0.9 \mathrm{~km}$ away from the $\mathrm{CO} 2$ Pilot site. Table 1 summarizes the maximum 1-h ground-level concentrations estimated by AERMOD for the whole experiment and the respective locations.

\section{Results and discussion}

\subsection{Modeling results}

$\mathrm{CO}_{2}$ atmospheric concentrations at ground level were calculated by AERMOD, based upon the premises presented before. Figure 2 shows the isoconcentration curves displayed in ppmv (parts per million by volume in air), illustrating the spatial distribution for the $200 \mathrm{~m} * 200 \mathrm{~m}$ receptor grid and Table 1 summarizes the average concentration for the discrete receptors of interest to the study, with respective UTM coordinates.

The first maximum 1-h ground-level concentration value was less than 20 ppmv, located downwind of the $\mathrm{CO}_{2}$ injection well and next to the experimental cell. Consistent with the small magnitude of the release and the overall high atmospheric dilution, average ground-level concentrations ranged from less than 0.5 to less than $20 \mathrm{ppmV} \mathrm{CO}_{2}$.

Once there are no air quality standards applicable to $\mathrm{CO}_{2}$ atmospheric concentrations, occupational health standards may be used as benchmarkings so as to compare with modeled results. According to a recent survey of the current $\mathrm{CO}_{2}$ maximum exposure levels $[16,17]$, all the calculated concentrations were at least three to several orders of magnitude lower than the standard limits in practice, that range from $5,000 \mathrm{pmv}$ ( $8 \mathrm{~h}$ standard) to $30,000 \mathrm{ppmv}$ (short term exposure) on a world basis. 


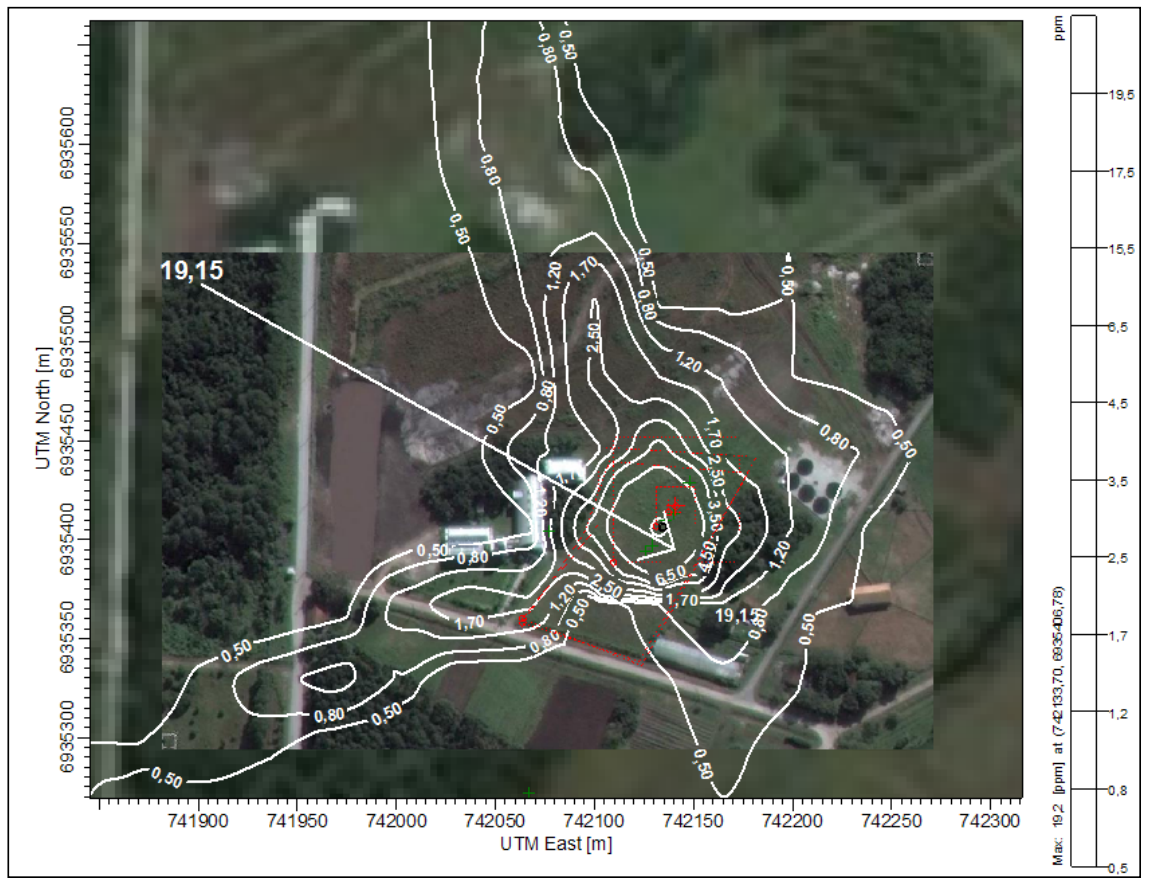

Figure 2: $\quad 1 \mathrm{~h}$ average ground level $\mathrm{CO}_{2}$ isocurves $-200 * 200 \mathrm{~m}^{2}$ receptor grid.

Table 1: AERMOD estimated max ground level 1-h $\mathrm{CO}_{2}$ concentrations.

\begin{tabular}{|c|c|c|c|}
\hline Parameter & $\mathrm{X}(\mathrm{m})$ & $\mathrm{Y}(\mathrm{m})$ & $\begin{array}{c}{\left[\mathrm{CO}_{2}\right]} \\
\mathrm{ppmV}\end{array}$ \\
\hline $\begin{array}{c}\text { Highest } 1^{\text {st }} \text { maximum } \\
\text { concentration }\end{array}$ & 742133.70 & 6935406.78 & 19.153 \\
\hline \multicolumn{4}{|c|}{ 1-h average concentrations at the receptors } \\
\hline TAPERA & 741504.76 & 6935287.28 & $8.1 * 10^{-5}$ \\
\hline Green building & 742067.05 & 6935271.88 & 0.011 \\
\hline Airport & 742195.24 & 6936435.10 & 0.011 \\
\hline Window & 742077.00 & 6935404.00 & 0.6019 \\
\hline Eddy covariance & 742148.00 & 6935429.00 & 5.044 \\
\hline
\end{tabular}

\subsection{Overview of the atmospheric detection main results}

Carried out in the September 2013 campaign, the atmospheric assessment included: (1) $\mathrm{CO}_{2}$ concentrations and fluxes measured by the Eddy Covariance; (2) $\mathrm{CO}_{2}$ concentrations and isotopic composition from the Isotopic Gas Analyzer. In order to save space, we restrict data illustration exclusively to the ECS $\mathrm{CO}_{2}$ concentration results (see Figure 3). For a detailed description of the sampling logistics for each method, as well as results assessment, refer to [13]. 
The measurements comprised: (1) a quick background survey (from $1^{\text {st }}$ to $9^{\text {th }}$ ); (2) the release experiment (from $10^{\text {th }}$ to $21^{\text {st }}$ ) and (3) short post injection survey (from $22^{\text {nd }}$ onwards), in which steady-state conditions were not probably reached.

Based upon the experimental results, the average values for the $\mathrm{CO}_{2}$ measured parameters were:

- at background conditions: (1) atmospheric concentrations of $396 \pm 41 \mathrm{ppmV}$;

(2) atmospheric fluxes of $-2.55 \pm 0.25 \mu$ mols.s $-1 \mathrm{~m}-2$, indicated a consistent sink behavior of the site (3) isotopic ratio (delta $13 \mathrm{C} / 12 \mathrm{C}$ concentration ratios) ranging from -6 to -15 ppmil;

- during the release: (1) atmospheric concentration range: 410-450 ppmV; (2) atmospheric flux ranging from -30 to $+20 \mu$ mols.s-1m-2; (3) isotopic ratio in the vicinities of -17 ppmil;

- after the injection ceased: (1) atmospheric concentrations declined from 450 back to ca $390 \mathrm{ppmV}$; (2) atmospheric fluxes of ca - $2.7 \mu$ mols.s-1m-2; (3) isotopic ratios ranging from -16 to -3 ppmil.

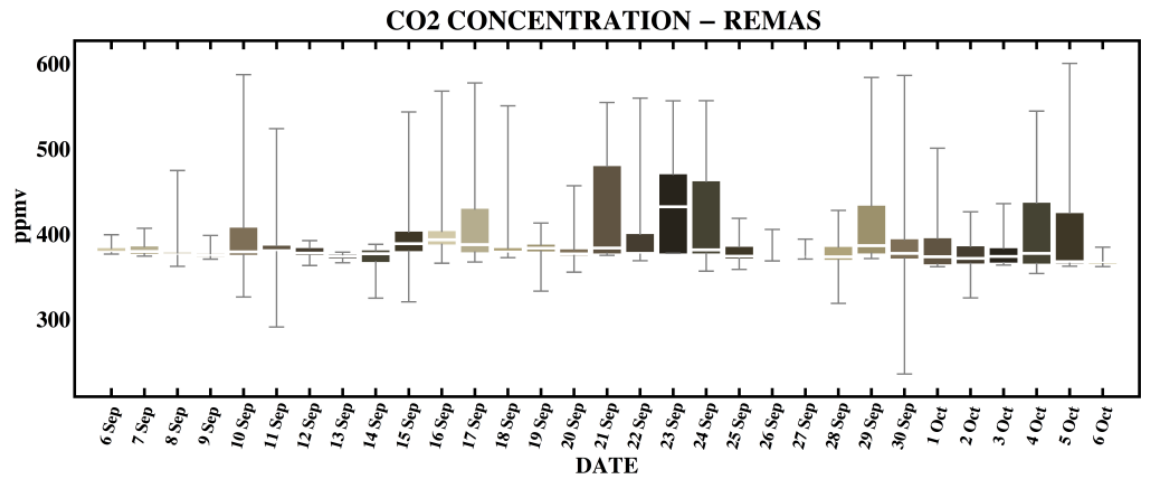

Figure 3: Eddy covariance $\mathrm{CO}_{2}$ atmospheric concentration plot for the 2013 release.

\section{Conclusions and perspectives}

Given the limited magnitude of the $\mathrm{CO}_{2}$ release experiment and considering the challenges imposed by the local background high variability, $\mathrm{CO}_{2}$ detection by the two monitoring sets was proven feasible and showed consistent trends. $\mathrm{CO}_{2}$ modeling by AERMOD reproduced the main features of the ECS results. The most relevant experimental findings were: (1) only very discrete changes in $\mathrm{CO}_{2}$ atmospheric fluxes (not shown) and concentrations (as shown in Figure 3) were recorded, likely to be attributed to our release experiment; (2) atmospheric background fluxes and concentrations roughly fall within the same range as of similar profile locations, as indicated by current literature [7, 8]; (3) the most significant contributions of our release experiment were perceived during day 
time with average surface winds blowing from southern quadrants, in which a discrete net build-up was also detected by ECS (to which other sources may have added as well); (4) in spite of the different coverage specificities of the two monitoring sets, both in terms of space and time, the experimental results show similar, consistent trends in the local $\mathrm{CO}_{2}$ dynamics; (5) once the IGA sampling was predominantly performed on the leaking spots within the experimental area, as illustrated in Figure 1 and described in [13], the qualitative matching of modeled results with measured data is limited to the ECS assessment solely.

For the whole period, the highest estimated concentration of ca 19 ppmv, falling within the cell boundaries, and the maximum 1-h average value of ca 5 ppmv, forecast by AERMOD for the ECS receptor, are consistent with the records for three days (17th to 19th September), in which higher winds blowing from south were likely to have contributed to the advection of the $\mathrm{CO}_{2}$ plume towards the ECS sensor (mounted upwind of the injection well, given the prevailing northernly surface winds).

For the next campaign, we plan to: (1) run longer lasting injections at higher release rates, to potentially enhance the leakage signature above natural background levels; (2) deploy automatic multiplexation for the IGA sampling, in order to optimize spatial coverage for the leaking hot spots within the experimental cell; (3) include other relevant local $\mathrm{CO}_{2}$ sources in the dispersion modeling.

\section{References}

[1] Intergovernmental Panel on Climate Change (IPCC). Climate Change 2014: Impacts, adaptation and vulnerability. Available at http://ipccwg2.gov/ AR5.

[2] $\mathrm{CCP}$ - Carbon dioxide capture for storage in deep geological formationsResults from the $\mathrm{CO} 2$ capture project. Volume 3: Advances in $\mathrm{CO} 2$ capture and storage technological results. BP Corp North America, 2009.

[3] National Energy Technology Laboratory (NETL). Monitoring, verification and accounting of CO2 stored in deep geological formations, 2009.

[4] International Energy Agency (IEA). Technology Roadmap Carbon Capture and Storage. OECD/IEA. (2013). Available online at http://www.iea.org/ publications/freepublications/publication/ (accessed in December, 2014).

[5] Feitz, A.J., Leamon, G., Jenkins, C., Jones, D.G., Moreira, A., Bressan, L., Melo, C., Dobeck, L.M., Repasky, K. and Spangler, L.H. Looking for leakage or monitoring for public assurance? Energy Procedia, 63, 38813890, 2014.

[6] International Energy Agency (IEA). Quantification techniques for $\mathrm{CO} 2$ leakage. OECD/IEA, 2012.

[7] Spangler, L.H., Dobeck, L.M., Repasky, K., Nehrir, A., Humphries, S.D., Barr, J., Keith, C., Shaw, J., Rouse, J., Cunningham, A., Benson, S., Oldenburg, C., Lewicki, J., Wells, A., Diehl, R., Strazisar B., Fessenden, J., Rahn, T., Amonette, J., Barr, J., William, P., Jacobson, J., Silver, E., 
Male, E., Rauch, H., Gullickson, K., Trautz, R., Kharaka, Y., Birkholzer, J., Wielopolski, L. A shallow subsurface controlled release facility in Bozeman, Montana, USA, for testing near surface $\mathrm{CO} 2$ detection techniques and transport models. Env Earth Sci, 60, 227-239, 2010.

[8] Lewicki J.L., Hilley G.E., Fischer M.L., Pan L, Oldenburg C.M., Dobeck L, Spangler L. Eddy covariance observations of surface leakage during shallow subsurface CO2 releases. J. Geophys. Res. 114, 2009.

[9] United States Environmental Protection Agency (USEPA) AERMOD: Description of model formulation. EPA-454/R-03-004. 2004. http://www.epa.gov/scram001/7thconf/aermod/aermod_mfd.pdf

[10] Seabra, P.N.C. EMISSIONS Technological Program. CENPES/ PETROBRAS. Personal communication, 2015.

[11] Peel, M.C., Finlayson, B.L., McMahon, T.A. Updated world map of the Köppen-Geiger climate classification. Hydrol. Earth Syst. Sci.11: 16331644. ISSN1027-5606, 2007.

[12] Oliva, A., Moreira, A.C.C.A., Melo, C., Bressan, L., Ketzer, J.M., Constant, M., Lazzarin, H., Cavelhão, G., Rosário, F., Musse, A.P., Corseuil, H., Hung Kiang Chang. A comparison of three methods for monitoring $\mathrm{CO} 2$ migration in soil and shallow subsurface in the Ressacada pilot site, Southern Brazil. Energy Procedia, 63, 3992-4002. 2014.

[13] Moreira, A.C.C.A., Landulfo, E., Nakaema, W., Marques, M., Medeiros, J., Musse, A.P., Rosario, F, Spangler, L.H., Dobeck, L.M. The first Brazilian Field Lab fully dedicated to $\mathrm{CO} 2 \mathrm{MMV}$ experiments: a closer look at atmospheric leakage detection. Energy Procedia, 63, 6215-6226. 2014.

[14] http://www.Redemet.aer.mil.br (accessed in January 2015).

[15] Thé, J.L. AERMETView Meteorological preprocessor user guide. Lakes Environmental Software. Waterloo Ontario Canada, 2015.

[16] National Institute for Occupational Safety and Health. NIOSH. Available at http://www.cdc.gov/niosh/pel88/124-38.html. Access in April, 2015.

[17] EC Directive 2006/15/EC available at http://eur-lex.europa.eu/legalcontent/EN/TXT/?uri=CELEX:32006L0015 (accessed in April, 2015). 